\title{
EUROPEAN INDUSTRIES CUSTOMER CENTRICITY ROADMAP STAGE - BUSINESS PROCESS MANAGEMENT ASPECT
}

\section{Milomir Vojvodic, Christian Hitz*}

\begin{abstract}
This research compares customer-centric strategies against product-centric strategies as different dimensions of competition, from a need for a more purposeful and clear concept of customer centricity (CC). It aims to contribute to a general roadmap for CC, as one strategic management direction and to prevail over the key managerial challenges to achieve it. The goal of the paper is to examine current maturity in adopting CC to scrutinise business process management (BPM) - a key dimension of transformation in the CC roadmap.

This paper uses deductive analysis to constitute an analytic theory and structure for evaluation then uses 18 case studies as an evaluation of the analytic theory. Evidence of movement on the customer-centric roadmap is found. BPM in European telecommunications, banking, utility, and retail sectors support the roadmap for CC from the process view, the process alignment and the process optimisation. However, the movement is partial and not flawless, as BPM has not been examined in terms of supporting many of the customer-centric dimensions.

Companies have a need for clarity, feedback, and the tools to succeed in an increasingly competitive and demanding world which, in the years to come, may demand a customer-centric approach in order to compete. In parallel, the work theoretically contributes to the importance of the relationship between CC and BPM and provides the first data analysis of its intersection.
\end{abstract}

Keywords: customer centricity, strategic management, business process management JEL Classification: M10, M20, L10

\section{Introduction}

All of the perspectives and hypothesis of CC aim to make business as profitable as possible in the long term yet still many firms are struggling to utilise it. $\mathrm{CC}$ is still an undetermined and undervalued concept, in contrast to the many definitions and the hype, which also contributes to the hesitancy and scepticism surrounding it. It is not clear if and how CC may be valuable to a company, the way to operationalise it, nor if every firm should consider all or just some of the aspects of it (Svensson and Gummesson, 2008). Hence, further debate is required to unveil the understanding of $\mathrm{CC}$ as a concept and its influence on the current business model.

The concept has almost become synonymous with the current management trend for customer care and service quality (Marsh, 2010). Kotler (2003) warned that customer focus, at its worst, is a boardroom buzzword, usually showing an awareness of a need although the actual event does not really address the issues.

* University of Economics, Prague, Faculty of Business Administration (vojm01@vse.cz). 
Although the outcome of CC may be beneficial and conventional, the means of it are radical. Essential confrontations that typically prevent a firm from evolving into $\mathrm{CC}$ are related to internal factors: organisational culture, structure, processes, and financial metrics (Shah et al., 2006; Fader, 2012).

Anand et al. (2014) warned that nowadays when markets are fast-paced with frequently changing customer needs and burgeoning technological developments, there is a significantly reduced probability of market dominance. Demanding and wellinformed customers are reinforcing the need for companies to start re-strategizing (Day, 2000). To avoid market lock-outs, sustainable models to react to changing needs and to develop new capabilities or provide products outside the current portfolio, are in high demand (Hollander et al., 2013). Social media and unprecedented access to information, such as peer-to-peer product and service reviews, are giving greater power to consumers, creating better informed and demanding customers and who buy more products from companies they trust (Edge, 2014).

This study addresses the need for CC to lead to something more meaningful and be what it might be at its best - a strategic management direction for the future of business. Similar to (De Wit and Meyer, 2004), it compares CC versus product-centric strategies as different dimensions of competition.

This paper endeavours to furnish a general roadmap for comprehending and prevailing over the key managerial challenges for achieving CC. Eventually, this work examines current maturity in support of the CC construct in business process management - one of the key dimensions in the $\mathrm{CC}$ roadmap.

This leads to the following:

- SUPPORTING RESEARCH QUESTIONS: Does BPM support customeroriented processes and how? Does BPM evidence a shift towards CC?

- MAIN RESEARCH QUESTION: What is the current level of application of BPM tools in support of a roadmap towards a customer-centric model?

Although there are several papers that address process management and $\mathrm{CC}$, there is still an insufficiently elaborated field of research. The theoretical background to the potential that such a connection carries does exist although there are no 'reality checks' on the current stage of implementation of BPM aimed at supporting CC.

The issue often addressed is that aligning corporate structure around customers only yields results in specific industries and competitive environments and that the benefits of increased customer satisfaction diminish if competitors have already adopted CC structures, if they leave the needs of a few unique customers unaddressed, and in less profitable industries (Lee et al., 2015). Some studies reveal that a corporate-level customer-centric structure translates to greater customer satisfaction, but simultaneously adds coordinating costs (Gaurav, 2016).

Search strategies with relevant keywords were used to identify literature from seven prestigious academic databases, namely 1) ACM Digital Library; 2) ProQuest; 3) EBSCO; 4) Science Direct; 5) Scopus; 6) Springer Link; 7) Web of Science, and one industry research database, namely Gartner. In addition, the study used Google Scholar to identify further literature related to the CC and BPM research topic. From the review, 430 articles were found during the initial search and 270 relevant articles were filtered 
out. Subsequently, twelve of the relevant articles were selected to discuss the association between CC and BPM.

\section{Theoretical Framework}

\subsection{Literature Review}

Search strategies with relevant keywords were used to identify literature from seven prestigious academic databases, namely 1) ACM Digital Library; 2) ProQuest; 3) EBSCO; 4) Science Direct; 5) Scopus; 6) Springer Link; 7) Web of Science, one industry research database, namely Gartner and three enterprise IT consulting companies. In addition, the study used Google Scholar to identify further literature related to the CC and BPM research topic. From the review, 430 articles were found during the initial search and 325 relevant articles were filtered out. Subsequently, only 12 were selected to discuss the association between CC and BPM. Other relevant articles are still incorporated in this research and cited as they are relevant to discussing CC or BPM, even without associating one with the other.

\subsection{Definition of Customer Centricity}

We can already see the origins of the thinking behind CC in the summary by Shah et al. (2006) where the importance of customer focus in going to market functions was first recognised and followed by a development phase of factors such as customer satisfaction, customer service, and customer loyalty. Consequently, the researchers opened up discussions in terms of the shifts in management paradigms and moving from a goodscentred approach to a service-centred approach.

CC originates from the same foundational marketing philosophy (Levitt, 1960). The theory that information comes from the market has a major role in setting commercial plans. On the other hand, CC is about individual customer oversight and the interaction with that individual customer (Ramani and Kumar, 2008; Shah et al., 2006).

Fader (2012) defines CC as a strategy that aligns a company's development and delivery of its products and services with the current and future needs of a designated set of customers aimed at maximising their long-term financial value to the firm, with the focus on categorising those customers who matter most and devoting uneven resources to them. For Sheth et al. (2000), this is about fulfilling the demands of individual consumers or customers rather than those of market segments.

Firms should attempt to address their customers' needs methodically, instead of only satisfying isolated parts of them (Womack and Jones, 1997; Moormann and Palvolgyi, 2013). For Clerc (2017), this is about putting the customer at the centre, regardless of time. This examines the total customer lifetime value, does not end with buying products and is part of a bigger picture, part of a long-lasting business value. Svensson et al. (2008) already view the concept as a business philosophy.

Treacy and Wiersema (1997) refer to it as a competitive strategy that allows extreme personalisation - a solution designed specifically for the individual customer that requires in-depth customer knowledge as well as insights into a customers' business processes. As per Marsh (2010), this is about services that customers need rather than developing new products and persuading consumers to purchase them. 
Some leading authorities on organisation design accept the concept completely as a strategic principle for a wide range of businesses (Kates and Galbraith, 2007).

Hunsaker (2016) says that CC is rooted in motives and is enabled by a culture where the first priority is to strive to make it easier for customers to acquire and use the solutions they seek with every other activity being secondary. Marsh (2010) states that all the activities of a firm including those functions that are not customer facing are aligned around customer value-adding work.

Opposite to CC that is proactive, Bliss (2015) distinguishes 'customer focus' as an endeavour that is often highly reactive because it usually refers to the cycle of survey results. The results are revealed; the silos react independently, rinse and repeat. High 'customer satisfaction' or superior 'customer experience' compared to CC are not transformational-scale movements as they do not force a change in behaviour so have less impact on profitability (Kamakura et al., 2005).

$\mathrm{CC}$ can be hypothesised as a reflective construct with four dimensions of manifestation which should be highly correlated: (i) interactive customer relationship management to discover hidden needs; (ii) customer integration in new product development decisionmaking; (iii) internal integration of organisational structures, gathering and sharing information about the customer; (iv) external integration of other vendors to address the customisation required by customers (Lamberti, 2013).

Similar to De Wit and Meyer (2004), setting apart the CC organisation from its opposite, product-centric organisation, is one of the most direct ways to define it (Galbraith, 2005).

Treacy and Wiersema (1997) argue that product leadership as a competitive strategy aims to build a culture that continuously brings superior products to market where the corporate disciplines cultivated include research portfolio management and product management. Marsh (2010) aligns that stating a product-centred strategy strives to deliver the best product and that in itself opens up the market to new opportunities. Firms then find it more profitable to focus on adding net new fractions to the market with superior product accomplishments rather than being oriented towards existing users (Shah et al., 2006). For a customer-centric organisation, the strategy is to identify products for its customers and to look for methods for integration. With this, pricing is not the sum of the products in the solution but is calculated from the value delivered to the customer.

For de Clerck (2017), enhancing the value created by each customer is the financial goal of customer-centric firms as opposed to increasing revenue through each product.

Peppers and Rogers (2011) argue that product-centric success is measured by how many customers are reached and that this would represent market share, whereas customer-centric success is represented by a share of the customer's life that the company participates in.

Fader (2012) realises that CC delivers profits in a more sustainable fashion and generates profits for the long term. For Kotler (2003), price-driven organisations are forever concentrating on margins where competitor price is offered slightly lower so that the customer feels rationalised in switching because no loyalty has ever been built. Customer-driven organisations are less vulnerable to the competitive environment. The implicit specification of the product or service by the customer (Marsh, 2010) is a strategy that gives valuable data for further product development and specifications. Participation in creative work increases customer satisfaction, loyalty, and emotional 
engagement. In addition, market research requires less investment as it is difficult to find the comparatively same level of valuable data.

\subsection{Roadmap to Customer Centricity}

Achieving an operational customer-centric business model is complex and timeconsuming and the company often fails to achieve the expected change as it is unable to manage the level of organisational change required (Leather, 2014).

Fader (2012) confirms that adopting CC demands nothing less than a complete restructuring of an organisation that will position it to serve precisely the right customers at the expense of almost everything else and, for Marsh (2010), every department needs to become customer-centric, with the end customer in mind. Functional differences are usually deeply rooted in incentives, backgrounds, and interests (Day, 2000). An enterprise will have to be retooled to attain customer-centric success and a strategic change of this magnitude takes a severe short-term financial hit (Fader, 2012). Kotler (2003) states that to become customer-centric is a task of magnificent proportions, where educating an entire workforce to change in a way that is fundamentally $\mathrm{CC}$ costs the company much more than just the financial cost.

Changes in organisation structure are often an important prerequisite before one can address problems (Shah et al., 2006). All functional activities integrated and coordinated in delivering top class customer value is one such requirement. A firm's processes for developing and sustaining customer relationships differ from those aimed at previous strategies and also require radical restructuring and redesigning.

Hollander et al. (2013) state that barriers to a successful transformation that arise due to legacy systems and processes and poor quality or insufficient end-customer data, constrain many organisations. Strong organisational silos create barriers to share customer data or cooperate across functions and departments. The addition of new products or policies leads to the further proliferation of data silos with duplicated and inconsistent data.

The journey to deliver a mature customer-centric operating model may take years. An organisational transformation that is so significant is to be broken down into reasonable phased implementation. Focusing on early success initially needs to prove the case and gain organisational buy-in (Hollander et al., 2013).

Overall, the literature provides insufficient deliverables in investigating the settings for the implementation of CC (Lamberti, 2013). However, it is possible to identify five areas of transformation and restructuring that are constantly repeated in the literature as building blocks of a roadmap to CC (Table 1).

In the following sections, the paper: (i) isolates $\mathrm{CC}$ and the processes as one particular area of the customer-centric roadmap and provides more details on its theoretical background; (ii) places $\mathrm{CC}$ and processes in the wider context of business process re-engineering management strategy (BPR); (iii) introduces BPM as a means for design, administration, and the analysis of business processes and reviews its history with customer focus; (iv) discusses common ongoing BPM CC adoption patterns and bestpractices across different industries in the set of 18 European customer use cases. 


\begin{tabular}{|l|l|}
\hline $\begin{array}{l}\text { Area of transformation in customer-centric } \\
\text { roadmap }\end{array}$ & Literature \\
\hline CC and organisational culture & $\begin{array}{l}\text { (Hunsaker, 2016), (Marsh, 2010), (Shah et al., } \\
\text { 2006), (Abdallah, 2015). }\end{array}$ \\
\hline CC and leadership & $\begin{array}{l}\text { (Shah et al., 2006), (Thielsen Valentino, 2015), } \\
\text { (Galbraith, 2005), (Marsh, 2010), (Leather, } \\
\text { 2014), (Bliss, 2015). }\end{array}$ \\
\hline CC and organisational structure & $\begin{array}{l}\text { (Treacy and Wiersema, 1997), (Kotler, 2003), } \\
\text { (Day, 2000), (Shah et al., 2006). }\end{array}$ \\
\hline CC and metrics & $\begin{array}{l}\text { (Edge, 2014), (Shah et al., 2006), (Fader, 2012), } \\
\text { (Marsh, 2010). }\end{array}$ \\
\hline CC and information management & (Edge, 2014), (Shah et al., 2006). \\
\hline CC and processes & $\begin{array}{l}\text { This area is analysed in greater detail in } \\
\text { the following section. }\end{array}$ \\
\hline
\end{tabular}

Source: authors

\subsection{Customer Centricity and Processes}

Identified obstacles emerge, such as the absence of leadership, the stifling of cultures when there is a suspicion of ideas outside the status quo, management turmoil during the change initiative, lack of urgency and system deficiencies, which all mean that essential information is not available to management. Shah et al. (2006) attempt to offer a broad roadmap to becoming $\mathrm{CC}$ where one of the subjects of change involves redefining new horizontally realigned processes. Similarly, Marsh (2010) offers six core features for achieving $\mathrm{CC}$ including involving the consumer in the design process.

For Fader (2012), moving to CC requires three elementary efforts including building an effective process of continually examining the 'right customers' in terms of what they will demand going forward.

Reaching CC is possible via a set of activities, including mapping the customer journey process in order to truly understand the gaps, the true experiences and the emotions that customers are left with after a purchase (Thielsen Valentino, 2015)

Hollander et al. (2013) argue that a customer-centric operating model requires designing business processes that recognise different customer segment needs, the process of easy customer experience at every touch point across the customer lifecycle, a dialogue process and a decision-making process embedding a culture that places the customer at its heart.

The difference between customer satisfaction and the actual use of a product in customer processes is even more important for companies attempting to move from product-centric to a solution assembly type of provider (Moormann and Palvolgyi, 2013). 
Kotler (2003) suggests that particular departments are more customer faced than others, and processes, CC expertise, and an approach can be built and utilised starting from these. Positive items within a current business process that only involve minor modification could prove to be the basis for that.

Payne and Frow (2005) recognised five generic processes that are important for a firm to be customer-centric and each necessitates cross-functional integration: (i) a strategydevelopment process that also includes customer strategy; (ii) an exchange and dual value creation process; (iii) a multichannel integration process with all the customer touch points; (iv) an information-management process with customer data collection and data analysis; (v) a performance-assessment process that ties the company's actions to company performance.

Another key challenge concerning customer-centric processes is developing the ability to address individual customers at a level of personalisation that generates a superior response compared to any other (aggregated) levels of customer segmentation. This was empirically shown by Rust and Verhoef (2005). Information technology advancement expedites such customer-centric processes with (i) increased dialogues with the customer; (ii) collecting information about each of these dialogues; (iii) making this captured information available to others; (iv) analysing the collected information. From the systems point of view, a critical component of customer-centric organisations is a unified, comprehensive, and organisation-wide view of individual customers, irrespective of the products purchased or channels employed by the customer (Shah et al., 2006).

Levit (2004) summarises the theories derived from foundational marketing philosophy and while they mainly direct the information exchange between the line of businesses or between functions (Narver and Slater, 1990), CC decomposes functional boundaries into CC processes, disregarding the ideas of functions to some extent (Galbraith, 2005; Shah et al., 2006).

Grönroos and Ravald (2011) argue that a supplier's focus on business relationships should be to engage with their customers' business processes.

The points at which information management and business process management interconnect are where workflow can help to actively find the existing customer entry by initial search and avoid reduplicating the data later, acknowledgement of customers notifying organisations of changes, such as a change of address followed by business processes that ensure circulation of this information, workflow support for rules and policy enforcement; for example, these might state that certain actions must be accomplished within a number of hours (Chuck Ballard et al., 2013). Also, the precise insights derived from the centralised management of customer's information such as consumer behaviour, user patterns and other hidden knowledge could harmonise important business processes such as real-time control and demand forecasting. The quality front-end information management of consumer data can be used to improve processes and make transactions more streamlined and frictionless by, for example, pre-filling forms (simultaneously improving consumer experience), avoiding anything unnecessary for the customer and tailoring content and providing advice (Moormann and Palvolgyi, 2013). As well as benefitting consumers by improving the quality of interactions, firms can identify strategic and efficiency improvements. 


\subsection{Customer Centricity and Business Process Re-engineering}

Management strategy aimed at helping organisations fundamentally rethink how they work in order to dramatically improve customer service is business process re-engineering (BPR) (Brock, 1995). Many processes should be removed instead of made faster through automation as the majority of the work done does not add any value to the customers (Hammer, 1990).

Re-engineering sheds light on the fact that an organisation's business processes are fragmented into sub-processes and then controlled by several specialised functions across the organisation while there is no role that is responsible for the overall performance of the entire process. As a result, the operating model is built on questionable assumptions in terms of the wants and needs of its customers.

Bock (2017) states that it is clear that driving growth in the experience economy means putting customers first, but their memorable service moments depend on compelling digital interactions with connected employees. Simple customer and simple employee digital experiences are anything but easy to deliver. It also requires 'digital' process design thinking, which is far more agile and incremental than traditional requirements analysis, with high bandwidth conversations and almost immediate release of new capabilities.

As per Hollander et al. (2013), the first step towards CC is to start developing new capabilities or provide products outside the current portfolio. Agile processes, based on $\mathrm{BPR}$, are opening opportunities to quickly outsource non-strategic functions and provide a complete solution that fulfils the missing need quickly. Still, the core requirement is the efficiency and effectiveness of smooth process across the value chain.

The key to improving customer retention is to remove the reasons why customers consider leaving in the first place. Use of predictive models can target customers based on the likelihood of lapse and the value of retention, but 'test and learn' approaches, via the agile framework of business processes, are essential to determine the interventions that are the most effective (Hollander et al., 2013).

However, major changes to business processes have a direct effect on job roles and workplace culture. Changing them simultaneously is an extraordinary task as stated by Covert (1997) and requires leadership. BPR involves more than one area within the organisation and it is important to have the support of all the concerned functions. Al-Mashari (2000) suggests that an important ingredient of any BPR effort must be cultural adjustment techniques and those that deal well with resistance.

$\mathrm{CC}$ is widely supported by BPR. It is essential that the automation infrastructure of the BPR activity provides for performance measurements in order to support continuous improvements and progress on some of the customer-oriented metrics that could be considered as a tool to help the acknowledgement and further progress of BPR.

Both, CC and BPR have similar characteristics such as the need for strong leadership, organisational structural and cultural change issues and addressing resistance. Eventually, if started at the same time, BPR and CC can be combined as operational efficiency core competency strategies. The shift towards a customer-centric model can be the introduction of a successive and ongoing enhancement that aligns with strategic business processes while moving away from functional silos (Vakola et al., 2000)

$\mathrm{CC}$ will 'protect the core' and provide the ability to catch up with the leading competitors. Still, to genuinely leapfrog the competition and generate significant growth 
there is a need to trigger a wider strategic management concept, such as BPR (Hollander et al., 2013). A new culture of innovation is required, where the empowered employees can identify and act on improvements and so that they become the new norm, similar to physical spaces such as innovation centres that are expected to continually incubate new ideas.

\subsection{Customer Centricity and Business Process Management}

Business process management is concepts, methods, and techniques that aid the design, administration, configuration and analysis of business processes (Weske, 2007). Business performance is increased by enhancing BPM processes over modifying the organisational setup, technology and process, human competency and motivation (Vom Brocke and Rosemann, 2014; Burlton, 2001).

BPM also supports transforming customer requirements into actual goods and services (Smart et al., 2009) while the literature on BPM is full of references to customer orientation. Business Process Management and the Lean Management approach to organisational management repeatedly highlights the customer as the initial point of all company activities (Hammer and Champy, 1993; Roos, 1990).

BPM approaches tend to focus on optimising time, costs and the quality of processes rather than on satisfying customer needs (Smolnik et al., 2011).

Even customer satisfaction and customer relations development is a declarative endgoal in BPM (Neubauer, 2009; Schmiedel et al., 2015). Most academic and practitioner endeavours that target business process optimisation concentrate on refining intraorganisational processes (Jurisch et al., 2014; Buh et al., 2015). BPM is still largely implemented with an internal focus and ways of relaying it to customers have already been observed (Flint et al. 2005). Customer value creation is often ignored in such insideout methodologies in BPM (Burlton, 2001).

Companies have to re-engineer their business processes for customer satisfaction based on BPM knowledge (Röglinger et al., 2012). BPM is built on the theory that a processcentred approach will lead to a considerable positive change in system performance (Vom Brocke and Rosemann, 2010). Firms are designed over segregated functional silos, generally forgetting important connecting processes that are supposed to provide service for the customer. BPM implies monitoring and optimising these silo-spanning business processes and utilising a process-oriented approach for judging and identifying outcomes for customers as opposed to hierarchies (McCormack, 2007). Vom Brocke and Rosemann (2010) raised weighing the priorities of front-end interaction with customers. Vom Brocke and Sinnl (2011) also identified 'customer orientation' as one of the core values of BPM. Kohlborn et al. (2014) suggest the 'outside-in' approach to BPM, starting with bearing customers' requirements in mind before anything else.

\section{Research Method and Findings}

\subsection{Research Method Description}

This paper has the aim of analysing the current level of customer-centricity in terms of BPM tools usage based on deductive analysis (Wilde and Hess, 2007). According to the notion of theory building as detailed by (Gregor, 2006), the operational definition of $\mathrm{CC}$ and the value aims of BPM explained in this paper constitute an analytic theory, 
and identify and structure the basic concept for the analysis of the current level of CC in terms of BPM tools usage. The research approach contains three steps.

The first step is an analysis of the scientific literature related to CC and BPM. Four academic online libraries were searched, namely the ACM Digital Library, EBSCO Online, and ProQuest while JSTOR was used as a search term

In the second step, all sources were examined and coded according to the operational definition of $\mathrm{CC}$ and the value aims of BPM explained in this paper. From the analysis of the data and the continuous comparison of the coded concepts, the list of the operational definition of CC was developed and three value aims of BPM were identified. Where the knowledge base could not be significantly enhanced anymore by the inclusion of additional search results, the procedure was terminated following the principle of theoretical saturation as argued by (Glaser, 1965).

In the third step, the theory underwent a critical appraisal through the use of 18 case studies. Case study research is an appropriate means of evaluation of analytic theories, in particular with regard to (Gregor, 2006) who stresses 'usefulness' and 'appropriateness' as evaluation criteria for this type of theory.

Eighteen case studies were used to assess the mapping of an operational definition of $\mathrm{CC}$ with value aims of BPM by means of empirical data from the phenomenon's natural context.

\subsection{Evaluation of Ongoing Customer-Centric BPM Patterns and Practices in Four Industries}

Business Process Management is an approach to aligning business strategy with execution. To discuss common ongoing BPM adoption patterns and best-practices across different industries, the set of 18 European customer use cases was analysed from an internal database of one of the global market leading vendor of BPM tool. According to Gartner Magic Quadrant for Intelligent BPM Suites, the vendor is a leader in the industry.

There are limitations in how the sample represents the population. The random sampling frame was not available. Still, there is representation from all parts of Europe, as well as variations in size, number of employees, number of customers served, services portfolio, size and type of end customers served, serving private, corporate and government clients, ownership and operating models, from small providers to those that offer services to $100 \%$ of the country population, the national operator, the biggest operator in a country, from only retailer to retailer and manufacturer, from utilities serving only private to those serving corporate and government clients, from a multichannel bank, operating through family bankers, operating via technological channels, to the representative of a country in the European System of Central Banks.

Of the observed firms, 7 out of 18 are from the region of Central and Eastern Europe, including one firm from the Commonwealth of Independent States (CIS), 7 from Southern Europe, 3 from Western Europe and 1 from Northern Europe.

The unit of analysis of the study is the telecommunications, banking, retail, and utility industries. All four industries are characterised by high IT spending, large data volumes, and intensive consumer interaction. 
Along with a clear understanding of the unit of analysis, case selection is crucial for building theory from case studies because it is case selection that determines the external validity of the case study (Patton, 2002), hence the limits for generalising the findings (Eisenhardt, 1989). The companies to be reviewed in the case study were selected on the basis that they are from Europe and that they have a sufficient amount of information within the case study to drive concessions, as well as that each case is no more than four years old.

The source of this information was semi-structured interviews with an account team that was documented in writing by BPM product managers. A major focus of interviews was to identify the potential that a case can be publicly or internally referenced in terms of how the software tool was used. The internal document that serves such a purpose was emailed to the account team and to the end customer. Examples of the questions were: What is the major and most valuable purpose of the BPM tool used? In which line of business it is used the most and what are the measurable benefits?

The cases do not represent all the existing customers of the given vendor, only those documented for internal share and reusability. Not all the cases are publicly referenced. Some of them were currently in the process of being publicly referenced where the process is lengthy and requires a number of approvals and documentation on both sides and some of the installations were not selected to be documented by the vendor, while some of the customers have an internal policy of not participating in such agreements in order not to disclose internal projects or to avoid publicity and inbound contacts for details.

From seven telecoms, all have usage associated with the customer-centric driver. Respective details from the other three industries are that from eight banks six have usage, from four utilities three have usage and from the two retailers, both of them have usage.

Each customer oriented drivers, challenges, implications, processes or values documented in the cases were attributed as a customer-centric pattern or practice and isolated in a separate list. All others were filtered out. There were amount drivers that we did not focus on in observations as they are not customer-centric; for example, the desire to improve internal productivity (by eliminating manual processes) or the need for change management caused by legal mandates or by industry standards for parity with peers.

In the analysis of ongoing customer-centric patterns or practices, the fundamental value of BPM was associated with three aims that are supposed to drive value. These are process optimisation (performance improvement in business-to-customer interaction) or process adaptability (fast response in process change resulting from shifting business needs in order to serve customers better) or process view (harmonising sales and customer service processes, thereby improving customer acquisition, walletshare, and retention). For each company, the content from the interview conducted was cross-checked against whether the value of BPM within the three aims is supposed to contribute to achieving CC per the operational definitions in Table 2. If the result was positive, a brief note was inserted in Table 3 as ongoing customer-centric pattern or practices. 


\section{Operational definitions of Customer-Centricity}

Customer-centricity that is proactive as opposed to 'customer focus' as efforts are often highly reactive (Bliss, 2015).

When setting up commercial plans, the focus is on the individual customer oversight and interaction with that individual customer, as opposed to the focus on information from the market (Ramani and Kumar, 2008; Shah et al., 2006).

Choosing a prime set of customers and maximising their long-term financial value to the firm, with the accent on identifying those customers who matter most and dedicating disproportionate amounts of resources to them (Fader, 2012).

Extreme personalisation - a solution designed specifically for the individual customer where this requires in-depth customer knowledge as well as insights into customers' business processes (Treacy and Wiersema, 1997).

Firms should attempt to address their customers' demands methodically, instead of fulfilling only isolated aspects (Womack and Jones, 1997; Moormann and Palvolgyi, 2013).

With the focus on a snapshot of a longer sequence of time that does not end with buying products, long-term profits are gained from the most valuable customers who buy more often, which helps to build a passionate, loyal customer base (Fader, 2012).

Organisational restructuring, removing organisational silos or a complex array of disparate product-centric systems (Shah et al., 2006).

Measurement is the evolving nature of the customer-firm relationship over time. The basis of this recognition is an understanding of metrics, such as customer lifetime duration, customer lifetime value, customer lifetime profit and understanding of the drivers behind them (Gupta and Zeithaml, 2006; Venkatesan and Kumar, 2004).

Integration of the diverse CC units (marketing, sales, service, product) or an organisational matrix with roles and authority giving focus back-end units to a particular customer (Day, 2000).

Profound understanding of customers' processes to guide them away from lower-level feature development or to take control and change the interactions and processes of the customers, provision of a complete solution (Moormann and Palvolgyi, 2013).

The authority that is in charge of $\mathrm{CC}$ initiative and is high on a hierarchical level or support roles (Marsh, 2010).

Source: authors

The aims also interact with themselves when it comes to customers' expectations of the value chain. The highest process optimisation will also drive value through process adaptability and the process view will also drive value through both process optimisation and process adaptability. The direction from process adaptability to the other two aims is less noticeable in some cases. 
Table 3 | The list of cases (codes used further in the paper are R-Retail, T-Telecommunications, B-Banking, U-Utilities)

\begin{tabular}{|c|c|}
\hline Code & European company \\
\hline R1 & $\begin{array}{l}\text { One of the largest private employers in a Southern European country and a multi- } \\
\text { billion dollar revenue, primarily engaged in the operation of retail stores. }\end{array}$ \\
\hline $\mathbf{R 2}$ & $\begin{array}{l}\text { Leading shoe manufacturer from a Southern European country with more than } \\
1000 \text { shops and several thousand employees. }\end{array}$ \\
\hline T1 & $\begin{array}{l}\text { Operator in a South-Eastern Europe country providing mobile communication services } \\
\text { to almost } 100 \% \text { of the population through its next-generation network. With roaming } \\
\text { agreements covering almost } 200 \text { countries. }\end{array}$ \\
\hline T2 & $\begin{array}{l}\text { One of the main broadband telecommunications company in a Southern-European } \\
\text { country. Fixed and mobile, optimised delivery of converged services including voice, } \\
\text { Internet, and television over a single broadband connection. }\end{array}$ \\
\hline T3 & $\begin{array}{l}\text { The national telecommunications operator in the Commonwealth of Independent } \\
\text { States and in CIS was one of the first operators to set up a next-generation network. }\end{array}$ \\
\hline T4 & $\begin{array}{l}\text { The biggest telecommunication operator in a Central European country, providing } \\
\text { network services for large companies and public institutions. }\end{array}$ \\
\hline T5 & $\begin{array}{l}\text { A leading telecommunication operator in a Central European country offering operator } \\
\text { services, data transmission, lease of lines, internet services, voice services, as well as } \\
\text { hosting and co-allocation. The core business is ensuring data transmission, especially } \\
\text { with VPN services. }\end{array}$ \\
\hline T6 & $\begin{array}{l}\text { Telco from a Southern European country with a significant presence in more than } \\
20 \text { countries and a customer base of over than } 300 \text { million accesses around the world. }\end{array}$ \\
\hline T7 & $\begin{array}{l}\text { South European telecommunications company, which provides telephony services, } \\
\text { mobile services, and DSL data services. }\end{array}$ \\
\hline B1 & $\begin{array}{l}\text { A multi-channel bank from a Southern European country, operating through } \\
\text { a commercial network of more than } 5,000 \text { family bankers and technological channels } \\
\text { through the internet, telephone, and mobile. }\end{array}$ \\
\hline B2 & $\begin{array}{l}\text { A Central European multinational financial services company, with operations in more } \\
\text { than } 50 \text { countries. }\end{array}$ \\
\hline B3 & $\begin{array}{l}\text { A financial services group operating in Northern Europe with more than } 1000 \text { branches } \\
\text { and active in } 20 \text { countries around the world. }\end{array}$ \\
\hline B4 & $\begin{array}{l}\text { A central bank in a Central European country representing the country in the European } \\
\text { System of Central Banks. }\end{array}$ \\
\hline B5 & $\begin{array}{l}\text { A commercial bank in Central Europe, handling various sizes of customers: big, small } \\
\& \text { medium companies and individuals. }\end{array}$ \\
\hline B6 & $\begin{array}{l}\text { A Western European bank that operates a wide variety of banking brands offering } \\
\text { personal and business banking, private banking, insurance and corporate finance } \\
\text { throughout its operations located in Europe, North America and Asia. }\end{array}$ \\
\hline U1 & $\begin{array}{l}\text { An energy network grid operator of electricity and gas in Western Europe. It serves } \\
\text { almost two million private, corporate and government clients. }\end{array}$ \\
\hline U2 & A water supply and treatment utility company in Western Europe. \\
\hline U3 & $\begin{array}{l}\text { Serves the energy sector in a South European country, employing } 4,000 \text { people } \\
\text { and generating revenues of almost } € 1 \text { billion. }\end{array}$ \\
\hline
\end{tabular}

Source: authors 
$\underline{\text { Retail }}$

\begin{tabular}{|c|c|c|}
\hline Process Adaptability & Process Optimisation & Process View \\
\hline $\begin{array}{l}\text { Process adaption towards } \\
\text { online and mobile technologies } \\
\text { (R1, R2) and social shopping } \\
\text { (R1) as customers segmented } \\
\text { on channel-specific purchase } \\
\text { cycles are no longer enough } \\
\text { due to today's complex } \\
\text { purchase journey that involves } \\
\text { touch-points across multiple } \\
\text { channels (R1, R2). }\end{array}$ & $\begin{array}{l}\text { Process support customer ac- } \\
\text { quisition, retention, and satis- } \\
\text { faction by consistent experienc- } \\
\text { es, whether shopping online or } \\
\text { offline (R1, R2), personalised } \\
\text { interaction and timely order } \\
\text { fulfilment (R1). Process inte- } \\
\text { gration for efficient client tick- } \\
\text { et processing with collabora- } \\
\text { tive features supplied through } \\
\text { the portal (R2). Addressing pro- } \\
\text { cess performance bottlenecks } \\
\text { in delivering seamless and last- } \\
\text { ing customer experiences in } \\
\text { quality post-sale service (R1). } \\
\text { Process connection of custom- } \\
\text { er experience across call-cen- } \\
\text { tre, outlet, and email channels } \\
\text { to try to reduce churn rate (R1). }\end{array}$ & $\begin{array}{l}\text { Setting a unified recency, } \\
\text { frequency, and monetary (RFM) } \\
\text { view of customer profitability } \\
\text { across multiple channels (R1). } \\
\text { Visibility for service process, } \\
\text { both for the customer and for } \\
\text { management (R1), complete } \\
\text { solution for managing end-to- } \\
\text { end customer service in post- } \\
\text { sales service and warranty } \\
\text { fulfilment (R2). }\end{array}$ \\
\hline
\end{tabular}

$\underline{\text { Telecommunications }}$

\begin{tabular}{|c|c|c|}
\hline Process Adaptability & Process Optimisation & Process View \\
\hline $\begin{array}{l}\text { Front-end process reconcilia- } \\
\text { tion due to declining voice rev- } \\
\text { enues from IP network-based } \\
\text { competition (T2, T3) and cus- } \\
\text { tomer demand for integrated } \\
\text { telephony, mobile, TV and in- } \\
\text { ternet services (T1, T2, T3, T4, } \\
\text { T7) than customer churn from } \\
\text { errors and delays in order man- } \\
\text { agement across order-capture } \\
\text { (T1, T2, T3) and order-provi- } \\
\text { sioning (T4, T7). Streamline } \\
\text { of service provisioning pro- } \\
\text { cesses for better customer ex- } \\
\text { perience in addressing channel } \\
\text { multiplications (T6, T7). Quick } \\
\text { process modifications of con- } \\
\text { tent and workflow anytime, } \\
\text { anywhere depending on cli- } \\
\text { ents' requirements (T1). Agility } \\
\text { in configuring new offerings or } \\
\text { modifying existing ones (T2). } \\
\text { Document access and search } \\
\text { related automation of business } \\
\text { processes (T5). Process sup- } \\
\text { port for adaptation of portals } \\
\text { optimised for different device } \\
\text { families due to the merger } \\
\text { of two companies (T6). }\end{array}$ & $\begin{array}{l}\text { Improve customer satisfaction } \\
\text { and ARPU average revenue } \\
\text { per user with timely accurate } \\
\text { provisioning of in-flight orders } \\
\text { and low error and abandon- } \\
\text { ment rates (T1, T2). Faster } \\
\text { order to cash cycle with a re- } \\
\text { duction in a number of excep- } \\
\text { tions (T2, T3, T4). Automate } \\
\text { different order management } \\
\text { processes, used for both fixed } \\
\text { and mobile offering (T2). Pro- } \\
\text { cess platform for rapid service } \\
\text { delivery and exchange with full } \\
\text { integration to existing customer } \\
\text { support systems (T3). Integrat- } \\
\text { ing manual document workflow } \\
\text { (invoices and correspondence } \\
\text { with partners) with the finan- } \\
\text { cial system and improve com- } \\
\text { munication with customers } \\
\text { (T4). }\end{array}$ & $\begin{array}{l}\text { Harmonisation and insight } \\
\text { into order-cycle processes, } \\
\text { across traditional system silos } \\
\text { and across multiple business } \\
\text { units, to deliver single-point- } \\
\text { of-contact (SPOC) converged } \\
\text { communication services for } \\
\text { businesses and consumers } \\
\text { and differentiate in their cus- } \\
\text { tomers' eyes (T1, T2, T7). } \\
\text { Design and implement a legal } \\
\text { contract process for a single } \\
\text { corporate view of contracts } \\
\text { history for internal purposes } \\
\text { and customer visibility (T1). } \\
\text { Business processes repository } \\
\text { to streamline sales customer } \\
\text { service (T3). }\end{array}$ \\
\hline
\end{tabular}

Source: authors 


\begin{tabular}{|c|c|c|}
\hline Process Adaptability & Process Optimisation & Process View \\
\hline $\begin{array}{l}\text { A process enabling a chron- } \\
\text { ological and yet agile view } \\
\text { of the payments flow (B1). } \\
\text { Flexible process infrastructure } \\
\text { on top of existing applications } \\
\text { to provide information regard- } \\
\text { ing the currencies exchange } \\
\text { rate for internal units and for } \\
\text { external users (B4). Quali- } \\
\text { ty user process experience } \\
\text { with dynamically re-routing } \\
\text { and delivering the right appli- } \\
\text { cation, to the right person for } \\
\text { the right task and at the right } \\
\text { time (B6). }\end{array}$ & $\begin{array}{l}\text { Single process management } \\
\text { connected to all systems of fi- } \\
\text { nancial data records and linked } \\
\text { to all sign-off personnel for } \\
\text { approvals leading to clear } \\
\text { accountability, proactive re- } \\
\text { porting and faster approvals } \\
\text { and customer satisfaction } \\
\text { (B3). Integrate front-office } \\
\text { payment initiation channels, } \\
\text { back-office ancillary systems, } \\
\text { and external counter-party } \\
\text { applications through common } \\
\text { payments pipe (B1). BPM to } \\
\text { represent the end-to-end jour- } \\
\text { ney of payments flow across } \\
\text { initiation, clearing, and settle- } \\
\text { ment, events being processes } \\
\text { triggered by different systems } \\
\text { (B5). }\end{array}$ & $\begin{array}{l}\text { Creation of a single, unified } \\
\text { middle office system by means } \\
\text { of process workflow, integra- } \\
\text { tion with legacy systems where } \\
\text { customer data and processes } \\
\text { are (B1). BPM platform for pro- } \\
\text { cess performance monitoring } \\
\text { of demanding project portfolio } \\
\text { to increase customer commu- } \\
\text { nication: customer data quality } \\
\text { management, client onboard- } \\
\text { ing, SWAPS trading order pro- } \\
\text { cess automation, hedge fund } \\
\text { ordering process, and lending } \\
\text { process (B2). To increase cus- } \\
\text { tomer satisfaction set faster } \\
\text { credit decision and increase } \\
\text { the visibility of the credit pro- } \\
\text { cess, history, and reports. } \\
\text { Have documents automatical- } \\
\text { ly transferred, triggering BPM } \\
\text { processes, immediate access } \\
\text { to human tasks (B5)? }\end{array}$ \\
\hline
\end{tabular}

Source: authors

Utility

\begin{tabular}{|c|c|c|}
\hline Process Adaptability & Process Optimisation & Process View \\
\hline $\begin{array}{l}\text { Providing business users } \\
\text { with the ability to quick- } \\
\text { ly and easily modify busi- } \\
\text { ness rules adapting them to } \\
\text { the business evolution (U1). } \\
\text { Complete revamp of customer } \\
\text { interaction around process- } \\
\text { es and application integration } \\
\text { to provide smart e-services } \\
\text { to consumers (U2). Upgrade } \\
\text { of current manual and very } \\
\text { error-prone processes around } \\
\text { replacement and checking me- } \\
\text { ters to address customers' dis- } \\
\text { satisfaction because of failed } \\
\text { appointments (U3). }\end{array}$ & $\begin{array}{l}\text { Automate the core business } \\
\text { processes purchase contract } \\
\text { order management (U1). Opti- } \\
\text { mise the standard work order } \\
\text { process around a meter that } \\
\text { involves many systems where } \\
\text { meter reading is a manual } \\
\text { and impractical process (U3). } \\
\text { Faster turnaround to user re- } \\
\text { ported outages (U2). }\end{array}$ & $\begin{array}{l}\text { Rising customer interest in } \\
\text { managing energy consump- } \\
\text { tion and maximising customer } \\
\text { wallet share with better de- } \\
\text { mand-supply planning driven } \\
\text { by process visibility (U1, U2). } \\
\text { Business people to view, anal- } \\
\text { yse and optimise the process- } \\
\text { es and make the meter to cash } \\
\text { process without errors in bill- } \\
\text { ing, revenue, customer service } \\
\text { and outage management (U3). }\end{array}$ \\
\hline
\end{tabular}

Source: authors

If lack of $\mathrm{CC}$ is in one way defined as that no one is responsible for the overall performance of the entire customer process then the process view aims of the BPM tool in this analysis of four industries can address that - involving clear and related roles, persons or departments who/which execute and own the processes, authority which, alone or jointly with others, determines the purposes and means of the processing. In the process view of BPM tools, 
a process owner always 'owns' all of the sub-processes of that process as well. In the BPM tool, the process owner is not only there for administration but also for leadership and care and the understanding of the cause of cross-functional customer process performance variations to propose a corrective course of action. The process view mission in 18 cases was also to support better insight into customers' experiences of their journeys, but also viewing which journeys have the greatest impact on overall business outcomes. Both approaches are normally long and slow in acquiring new types of information and assembling it in new ways. However, success allows management to clearly see the customer's experience and the causes of current performance from start to finish. The company's traditional customer-experience dashboard had missed the problem because it included no measure of end-to-end success. On the other side, from 18 cases only 3 of them evidenced that the process view will directly support some of the customer-centric metrics.

From the insufficient amount of information in the case studies, it is not possible to drive the conclusion of a customer-centric trend such as an intensive move from traditional functional orientation, for example, although it is obvious from the process adaptability patterns and practices that these four industries have invested in alignment with strategic business processes - those that face individual customers. The process adaptability section delivers, in our 18 cases, the expectations of a lightweight layer of a BPM tool supporting high-bandwidth conversations or far more agile and incremental traditional requirements analysis and the move towards 'digital process design thinking' as one of the CC signs. 'Test and learn' approaches, through an agile framework of business processes and process adaptability patterns and practices, in our observed European group are, overall, anticipated to determine which interventions are the most effective and can improve customer retention. As a basis, customer-centric process and expertise are indeed built and utilised starting from existing processes exposed to more customer-orientated departments.

While some companies were only seeking to solve a few evident issues in specific customer journeys over multi-channel, some of them used the detection of the key journeys that matter as a starting point to begin the transformation. Even such insight and decision itself are typically not so clear initially, such a process optimisation project generated support for programs addressing improvement and even broader organisational changes. Some of the early and simple process-optimised-successes set the direction for further transformation. Processes mapped to organisational changes proposed by CC are not found in an available set of information from the case studies. The root causes of poor customer experience often shine from the inside - from cross-functional disconnects. In our view of four industries in Europe - BPM usage was, in a few cases, demonstrated to process-optimise how cross-functional teams work together to see problems for themselves and thoroughly design solutions for customer requirements instead of fulfilling only isolated aspects. The evidence of tools supporting more rigid departmental boundaries elimination is not found.

In summary, evidence of movement on the customer-centric roadmap is found. BPM in European telecommunications, banking, utility, and the retail sector supports a roadmap towards customer-centricity in the process view, process alignment and process optimisation. It does initiate a change of the concept of customer focus further towards elements of CC: proactivity, individual customer, oversight and interaction with that individual customer, oversight of a selected set of customers, a snapshot of a longer time sequence of time that does not end with buying products. 


\begin{tabular}{|c|c|}
\hline Operational definitions of customer-centricity & $\begin{array}{l}\text { BPM usage evidenced* } \\
\text { in support of process } \\
\text { optimisation, process } \\
\text { view or process } \\
\text { adaptability }\end{array}$ \\
\hline $\begin{array}{l}\text { Customer-centricity that is proactive as opposed to 'customer focus' as } \\
\text { efforts are often highly reactive (Bliss, 2015). }\end{array}$ & Supported \\
\hline $\begin{array}{l}\text { When setting up commercial plans, the focus is on the individual } \\
\text { customer oversight and interaction with that individual customer, } \\
\text { as opposed to the focus on information from the market (Ramani } \\
\text { and Kumar, 2008; Shah et al., 2006). }\end{array}$ & Supported \\
\hline $\begin{array}{l}\text { Choosing a prime set of customers and maximising their long- } \\
\text { term financial value to the firm, with the accent on identifying those } \\
\text { customers who matter most and dedicating disproportionate amounts } \\
\text { of resources to them (Fader, 2012). }\end{array}$ & Supported \\
\hline $\begin{array}{l}\text { Extreme personalisation }- \text { a solution designed specifically for } \\
\text { the individual customer where this requires in-depth customer } \\
\text { knowledge as well as insights into customers' business processes } \\
\text { (Treacy and Wiersema, 1997). }\end{array}$ & Supported \\
\hline $\begin{array}{l}\text { Firms should attempt to address their customers' demands } \\
\text { methodically, instead of fulfilling only isolated aspects (Womack } \\
\text { and Jones, 1997; Moormann and Palvolgyi, 2013). }\end{array}$ & Supported \\
\hline $\begin{array}{l}\text { Focus on a snapshot of a longer sequence of time that does not end } \\
\text { with buying products; long-term profits are gained from most valuable } \\
\text { customers who buy more often, which helps to build a passionate, loyal } \\
\text { customer base (Fader, 2012). }\end{array}$ & Supported \\
\hline $\begin{array}{l}\text { Organisational restructuring, removing organisational silos or } \\
\text { a complex array of disparate product-centric systems (Shah et al., } \\
\text { 2006). }\end{array}$ & Not supported \\
\hline $\begin{array}{l}\text { Measurement is the evolving nature of the customer-firm relationship } \\
\text { over time. The basis of this recognition is an understanding of metrics, } \\
\text { such as e.g. customer lifetime duration, customer lifetime value, } \\
\text { customer lifetime profit and understanding of the drivers behind them } \\
\text { (Gupta and Zeithaml, 2006; Venkatesan and Kumar, 2004). }\end{array}$ & Not supported \\
\hline $\begin{array}{l}\text { Integration of the diverse } C C \text { units (marketing, sales, service, product) } \\
\text { or organisational matrix with the roles and authority giving focus back- } \\
\text { end units to a particular customer (Day, 2000). }\end{array}$ & Not supported \\
\hline $\begin{array}{l}\text { Profound understanding of customers' processes to guide them } \\
\text { away from lower-level feature development or to take control } \\
\text { and change interactions and processes of the customers, provisioning } \\
\text { of a complete solution (Moormann and Palvolgyi, 2013). }\end{array}$ & Not supported \\
\hline $\begin{array}{l}\text { The authority that is in charge of the CC initiative and is high on } \\
\text { a hierarchical level or for support roles (Marsh ,2010). }\end{array}$ & Not supported \\
\hline
\end{tabular}

*Evidenced in at least two from four industries as per data from Table 3.

Source: authors 
However, the evidence of the movement is 'halfway' as BPM has not been examined for supporting organisational restructuring, removing organisational silos or a complex array of disparate product-centric systems, integration of diverse CC units (marketing, sales, service, product) or an organisational matrix with roles and authority giving focus back-end units to a particular customer, profound understanding of customers' processes to guide them away from lower-level feature development or to take control and change the interactions and processes of the customers, provisioning of a complete solution, tailor-made - taking into account the specific applications by the client rather than standard products. No case has been evidenced of support for an authority that is in charge of a customer-centric initiative and is high on hierarchical level or of support roles, workflows or processes in measuring the evolving nature of the customer-firm relationship over time.

\section{Theoretical and Practical Contribution}

This research aims to contribute to a general roadmap for $\mathrm{CC}$, as one strategic management direction, and to prevail over the key managerial challenges to achieve it.

Companies are in a need for such clarity, feedback, and the tools to succeed in an increasingly competitive and demanding world that, in the years to come, may demand a customer-centric approach in order to compete. In parallel, the work theoretically contributes to the importance of the relationship between CC and BPM and provides the first data analysis of its intersection.

The paper further theoretically contributes to the clarity of the meaningful definition and purpose of CC as well as to roadmap in order to achieve the values from it. In parallel, the theoretical contribution is in the importance of the relationships between CC and BPM and where this work also provides a 'reality check' of the current of implementation stage of the latter in support of the former.

The authors contribute to the foundational marketing theory (Levitt, 1960) in interrelating CC and BPM concepts. They attempt to add value to the literature in four ways. First, by reviewing the overlap between research on CC and BPM concepts and second, by presenting a conceptual framework for incorporating BPM into the CC line of research. The framework clarifies the relationship between the two. Third, there is an empirical test of some of the critical relationships in the conceptual model that link $\mathrm{CC}$ and BPM. Fourth, we examine BPM in a new setting.

\section{Conclusions and Implications for Further Research}

Many of the concepts, including knowing absolutely everything about the best customers, have existed for a long time (Marsh, 2010). What is new, however, is the competitive landscape and the incredibly demanding world in which companies are conducting business, is a need for knowledge and tools to succeed in a world that, in the years to come, may demand a customer-centric approach to compete, as other approaches are no longer enough in many situations (Fader, 2012).

CC promises a competitive advantage in order to be significantly sustainable and not easily countered by competition (Shah et al., 2006). Many emerging factors have taken the full set of inherent advantages from traditionally successful models, and what can still 
remain are the relationships - that companies have or do not have with their customers. Customers are the link between the profit that is being made today and the profit that is likely to be made tomorrow. The customer relationship directly connects today's profits and costs to the company's overall shareholder value (Peppers and Rogers, 2011).

As this paper outlines, $\mathrm{CC}$ has the potential to provide considerable, and in some cases outstanding, values as a business strategy in the era of the consumer. It was shown that there is a roadmap for the development of CC to become a core competence in the recent dynamic and over-competitive environment.

However, for such $\mathrm{CC}$ - as a strategic management tool with a roadmap in this paper, the criteria are high. Such a direction of CC is a major change and is completely re-shaping the organisation. In order to be a change management best practice, a reference of appropriate organisational structure, processes, systems, and metrics transformation then the involvement of divisional and department heads and system owners subscribing to a single corporate vision is required.

The basis of a successful customer-centric approach start can be positive elements within current business processes that only require a minor change of emphasis and IT facilitated customer-centric processes. BPM approaches to organisational management often emphasise the customer as the starting point for all company activities and implement process design thinking, far more agile and incremental than traditional requirements analysis, with high bandwidth conversations. The evidence of movement on the customercentric roadmap is found in BPM usage in European telecommunications and the banking, utility and retail sectors where more than a third of firms were from Central and Eastern European countries.

However, the evidence of the movement is that it is somewhere 'halfway'. Customercentric business processes support a closer bond between firms and their customers and raise a company's competitive strength.

Customer-centric business processes support a closer bond between firms and their customers and raise a company's competitive strength. A shift towards a CC model can be the introduction of a successive and ongoing improvement strategy that to a greater extent is connected with business process management.

The essential priority is ensuring that CC becomes a key priority for the top management with principal methods of enabling leadership with strategic management, organisational psychology, information, change and BPM roadmaps to successfully steer their firms toward a customer-centric paradigm.

There is the obvious necessity of conducting in-depth research on a variety of specific issues that come from such general broad overviews. The concept of CC will continue to evolve in the upcoming period, as globalisation drivers further reshape customer properties and position and as technology announcements usually come with newer and better ways to collect, store, and analyse customer information. The burden to the researchers will be to explore evident issues that may offer additional insights to practitioners and to the strategic management field in general (Shah et al., 2006).

The field of research needs to follow the concept of CC that will continue to evolve in the upcoming period, as globalisation drivers further reshape customer properties and as advances in technology introduce newer and better ways to collect, store, and analyse customer information. 
If seen as a strategic management direction for the future of business, and a specimen of how business strategy can still respond and provide content for the urgent and significant changes in strategy context, then interesting areas for further research can be: $\mathrm{CC}$ as a strategy of operational excellence, as a core competence, a direction on how a competitive advantage could be found; a shift towards a $\mathrm{CC}$ model can be the introduction of a successive and ongoing improvement strategy and over a greater extent connected with BPR; potential long-term gains of $\mathrm{CC}$ as a widespread vision of loyalty as a value, broader loyalty business model as a whole, not only stimulated and expected from customers but also from employees, suppliers, distributors and shareholders; potential strategy that appropriately matches the tensions and perspectives of shareholder versus stakeholder tensions and outside-in versus inside-out.

\section{References}

Abdallah, E. (2015). The Five Essentials of Customer-Centric Cultures, [online]. ABC News. Available at: https://www.heidrick.com/Knowledge-Center/Article/The-five-essentials-ofcustomer-centric-cultures [Accessed 31 Mar. 2018]

Al-Mashari, M., Irani, Z. and Zairi, M. (2001). Business Process Reengineering: A Survey of International Experience. Business Process Management Journal, 7(5), pp. 437-455, https://doi.org/10.1108/14637150110406812

Anand, G., Chandrashekar, A. and Narayanamurthy, G. (2014). Business Process Reengineering Through Lean Thinking: A Case Study. Journal of Enterprise Transformation, 4, pp. 123-150, https://doi.org/10.1080/19488289.2013.879681

Bliss, J. (2015). Chief Customer Officer 2.0. Hoboken, N. J: John Wiley \& Sons, Inc.

Buh, B., Kovačič, A. and Stemberger, M. (2015). Critical Success Factors for Different Stages of Business Process Management Adoption - A Case Study. Economic Research, 28(1), pp. 243-258, https://doi.org/10.1080/1331677X.2015.1041776

Burlton, R. T. (2001). Business Process Management. Profiting from the Process. New York: Sams.

Chuck Ballard, A. T. and Dubov, L. (2013). Aligning MDM and BPM for Master Data Governance, Stewardship, and Enterprise Processes, [online]. Available at: http://www.redbooks.ibm.com/redbooks/pdfs/sg248059.pdf [Accessed 14 Apr. 2018]

Christin Jurisch, M., Palka, W., Wolf, P. and Krcmar, H. (2014). Which Capabilities Matter for Successful Business Process Change? Business Process Management Journal, 20(1), pp. 47-67, https://doi.org/10.1108/BPMJ-11-2012-0125

Clerck, J.-P. (2017). Customer Centricity - What It Means to Be Customer Centric, [online]. Available at: https://www.i-scoop.eu/customer-centricity [Accessed 31 Mar. 2015]

Covert, M. (1997). Successfully Performing Business Process Engineering, [online]. Visible Systems Corporation. Available at: https://www.csus.edu/indiv/r/rengstorffj/obe152spring02/articles/businessprocessreengineering.pdf [Accessed 28 Apr. 2018]

Day, G. S. (2000). Managing Market Relationships. Journal of the Academy of Marketing Science, 28(1), pp. 24-30, https://doi.org/10.1177/0092070300281003

De Wit, B. and Meyer, R. (2004). Strategy: Process, Content, Context: An International Perspective (3rd ed.). London: Thomson Learning.

den Hemel, C. van and Rademakers, M. F. (2016). Building Customer-Centric Organizations: Shaping Factors and Barriers. Journal of Creating Value, 2(2), pp. 211-230, https://doi.org/10.1177/2394964316647822 
Edge, J. (2014). Towards Customer Centricity - An Enterprise Vision of Information Management for Insurers, [online]. Informatica. Available at: https://now.informatica.com/en_towardscustomer-centricity_white-paper_3176.html [Accessed 31 Mar. 2018]

Eisenhardt, K. M. (1989). Building Theories from Case Study Research. The Academy of Management Review, 14(4), p. 532, https://doi.org/10.2307/258557

Fader, P. (2012). Customer Centricity: Focus on the Right Customers for Strategic Advantage. Wharton Executive Essentials. New York: Wharton Digital Press.

Flint, D. J., Larsson, E., Gammelgaard, B. and Mentzer, J. T. (2005). Logistics Innovation: A Customer Value-Oriented Social Process. Journal of Business Logistics, 26(1), pp. 113-147, https://doi.org/10.1002/j.2158-1592.2005.tb00196.x

Gaurav R. and Shainesh G. (2017). The Changing Face of Customer Centricity. In H. Ellermann, P. Kreutter and W. Messner, eds. The Palgrave Handbook of Managing Continuous Business Transformation, pp. 175-187. London: Palgrave Macmillan.

Gersch, M., Hewing, M. and Scholer, B. (2011). Business Process Blueprinting - An Enhanced View on Process Performance. Business Process Management Journal, 17(5), pp. 732-747, https://doi.org/10.1108/14637151111166169

Glaser, B. G. (1965). The Constant Comparative Method of Qualitative Analysis. Social Problems, 12(4), pp. 436-445, https://doi.org/10.2307/798843

Gregor, S. (2006). The Nature of Theory in Information Systems. MIS Quarterly, 30(3), pp. 611-642, https://doi.org/10.2307/25148742

Grönroos, C. and Ravald, A. (2011). Service as Business Logic: Implications for Value Creation and Marketing. Journal of Service Management, 22(1), pp. 5-22, https://doi.org/10.1108/09564231111106893

Gummesson, E. (2008). Customer Centricity: Reality or a Wild Goose Chase? European Business Review, 20, pp. 315-330, https://doi.org/10.1108/09555340810886594

Gupta, S. and Zeithaml, V. (2006). Customer Metrics and Their Impact on Financial Performance. Marketing Science, 25(6), pp. 718-739, https://doi.org/10.1287/mksc.1060.0221

Hammer, M. and Champy, J. (1993). Reengineering the Corporation: A Manifesto for Business Revolution. New York: HarperBusiness.

Hollander, D., Hertz, K. and Klein Wassink, B. (2013). The Journey Toward Greater Customer Centricity. [online] Ernst \& Young. Available at: https://www.ey.com/Publication/ vwLUAssets/The_journey_toward_greater_customer_centricity_-_US/\%24FILE/ Customer_Centricity_Paper_29_April_Final_US.pdf [Accessed 31 Mar. 2017]

Hunsaker, L. (2016). Customer-Centricity Goes Beyond Customer Experience Management. [online] Customer Think. Available at: http://customerthink.com/customer_centricity_ goes_beyond_customer_experience_management/ [Accessed 31 Mar. 2015]

Jurisch, M., Ikas, C., Wolf, P. and Krcmar, H. (2013). Key Differences of Private and Public Sector Business Process Change. e-Service Journal, 9(1), pp. 3-27, https://doi.org/10.2979/eservicej.9.1.3

Kamakura, W. et al. (2005). Choice Models and Customer Relationship Management. Marketing Letters, 16(3-4), pp. 279-291, https://doi.org/10.1007/s11002-005-5892-2

Kates, A. and Galbraith, J. R. (2007). Designing Your Organization: Using the STAR Model to Solve 5 Critical Design Challenges. San Francisco: Jossey-Bass.

Kotler, P. (2003). Marketing Insights from A to Z: 80 Concepts Every Manager Needs to Know. Hoboken, N. J.: John Wiley \& Sons. 
Lamberti, L. (2013). Customer Centricity: The Construct and the Operational Antecedents. Journal of Strategic Marketing, 21(7), pp. 588-612, https://doi.org/10.1080/096525 4X.2013.817476

Leather, D. (2014). The Challenges of Implementing Customer-Centric Strategy - What Creates the Problem? [online] Customer Think. Available at: http://customerthink.com/ the-challenges-of-implementing-customer-centric-strategy-what-creates-the-problem [Accessed 31 Jun. 2017]

Lee, J.-Y., Sridhar, S., Henderson, C. M. and Palmatier, R. W. (2015). Effect of Customer-Centric Structure on Long-Term Financial Performance. Marketing Science, 34(2), pp. 250-268, https://doi.org/10.1287/mksc.2014.0878

Levitt, T. (1960). Marketing Myopia. Harvard Business Review, 82 (7-8), pp. 138-149.

Marsh, C., Sparrow, P. R. and Hird, M. (2010). Is Customer Centricity A Movement Or Myth? Opening Debate for HR. University of Lancaster.

McCormack, K. (2007). Business Process Maturity: Theory and Application. BookSurge Publishing.

Moormann, J. and Palvolgyi, E. Z. (2013). Customer-Centric Business Modelling: Setting a Research Agenda [Conference Proceedings]. IEEE 15th Conference on Business Informatics (CBI), pp. 173-179, https://doi.org/10.1109/CBI.2013.33

Narver, J. C. and Slater, S. F. (1990). The Effect of a Market Orientation on Business Profitability. Journal of Marketing, 54(4), pp. 20-35, https://doi.org/10.2307/1251757

Neubauer, T. (2009). An Empirical Study about the Status of Business Process Management. Business Process Management Journal, 15(2), pp. 166-183, https://doi.org/10.1108/14637150910949434

Patton, M. Q. (2002). Qualitative Research \& Evaluation Methods (3rd ed.). Thousand Oaks: Sage.

Payne, A. and Frow, P. (2005). A Strategic Framework for Customer Relationship Management. Journal of Marketing, 69(4), pp. 167-176, https://doi.org/10.1509/jmkg.2005.69.4.167

Peppers, D. and Rogers, M. (2011). Managing Customer Relationships: A Strategic Framework (2nd ed.). Hoboken, N. J.: John Wiley.

Ramani, G. and Kumar, V. (2008). Interaction Orientation and Firm Performance. Journal of Marketing, 72(1), pp. 27-45, https://doi.org/10.1509/jmkg.72.1.27

Roglinger, M., Poppelbus, J. and Becker, J. (2012). Maturity Models in Business Process Management. Business Process Management Journal, 18(2), pp. 328-346, https://doi.org/10.1108/14637151211225225

Roos, D. (1990). The Machine That Changed the World. New York: Scribner Book Company.

Ross, J. (1990). Total Quality Management: Text, Cases and Readings. Boca Raton, Fla.: St. Lucie Press.

Rust, R. T. and Verhoef, P. C. (2005). Optimizing the Marketing Interventions Mix in Intermediate-Term CRM. Marketing Science, 24(3), pp. 477-489, https://doi.org/10.1287/mksc.1040.0107

Shah, D., Rust, R. T., Parasuraman, A., Staelin, R. and Day, G. S. (2006). The Path to Customer Centricity. Journal of Service Research, 9, pp. 113-124, https://doi.org/10.1177/1094670506294666

Sheth, J. N., Sisodia, R. S. and Sharma, A. (2000). The Antecedents and Consequences of Customer-Centric Marketing. Journal of the Academy of Marketing Science, 28(1), pp. 55-66, https://doi.org/10.1177/0092070300281006 
Smart, P. A., Maddern, H. and Maull, R. S. (2009). Understanding Business Process Management: Implications for Theory and Practice. British Journal of Management, 20(4), pp. 491-507, https://doi.org/10.1111/j.1467-8551.2008.00594.x

Smolnik, S., Gersch, M., Hewing, M. and Schöler, B. (2011). Business Process Blueprinting An Enhanced View on Process Performance. Business Process Management Journal, 17, pp. 732-747, https://doi.org/10.1108/14637151111166169

Thielsen Valentino, A. (2015). 10 Tips - Customer Centricity as a Strategic Management Tool. [online] Loyalty Group. Available at:

https://www.loyaltygroup.dk/eu/news-inspiration/article-archive/2015/10-tips-customercentricity-as-a-strategic-management-tool [Accessed 1 Apr. 2017]

Treacy, M. and Wiersema, F. D. (1997). The Discipline of Market Leaders: Choose Your Customers, Narrow Your Focus, Dominate Your Market. New York: Basic Books.

Vakola, M., Rezgui, Y. and Wood-Harper, T. (2000). The Condor Business Process Re-Engineering Model. Managerial Auditing Journal, 15(1/2), pp. 42-46, https://doi.org/10.1108/02686900010304623

Venkatesan, R. and Kumar, V. (2004). A Customer Lifetime Value Framework for Customer Selection and Resource Allocation Strategy. Journal of Marketing, 68(4), pp. 106-125, https://doi.org/10.1509/jmkg.68.4.106.42728

Vom Brocke, J. and Rosemann, M., eds. (2014). Handbook on Business Process Management 1 \& 2. Berlin: Springer.

Vom Brocke, J. et al. (2014). Ten Principles of Good Business Process Management. Business Process Management Journal, 20(4), pp. 530-548, https://doi.org/10.1108/BPMJ-06-2013-0074

Vom Brocke, J. and Sinnl, T. (2011). Culture in Business Process Management: A Literature Review. Business Process Management Journal, 17(2), pp. 357-377, https://doi.org/10.1108/14637151111122383

Weske, M. (2007). Business Process Management. London: Springer-Verlag.

Wilde, T. and Hess, T. (2007). Forschungsmethoden der Wirtschaftsinformatik. WIRTSCHAFTSINFORMATIK, 49(4), pp. 280-287, https://doi.org/10.1007/s11576-007-0064-z

Wit, B. and Meyer, R. (2004). Strategy: Process, Content, Context: An International Perspective (3rd ed.). Australia, London: Thomson Learning.

Womack, J. P. and Jones, D. T. (1997). Lean Thinking - Banish Waste and Create Wealth in Your Corporation. Journal of the Operational Research Society, 48(11), p. 1148, https://doi.org/10.1057/palgrave.jors.2600967

Womack, J. P., Jones, D. T. and Roos, D. (1990). The Machine That Changed the World: Based on the Massachusetts Institute of Technology 5-Million Dollar 5-Year Study on the Future of the Automobile. New York: Rawson Associates. 